\title{
Using Massive Open Online Course (MOOC) on Pancasila Education Increasing Students' Score
}

\author{
https://doi.org/10.3991/ijim.v14i12.15593 \\ Didik Sukriono $\left.{ }^{(}\right)$,Sudirman \\ UniversitasNegeri Malang, Jawa Timur, Indonesia \\ didik.sukriono.fis@um.ac.id
}

\begin{abstract}
This article analyzes the development of virtual learning capabilities through massive open online courses (MOOC) on Pancasila Education. The Pancasila Education course has only been delivered in traditionally managed classes by relying on face-to-face meetings. Therefore there needs to be a new approach in Pancasila education to deal with 21 st century learning. This research was designed as a research and development education (R\&D). Starts with developingthe MOOC Pancasila education platform and conducting tests on students. The research instrument used in this study was the learning outcomes (scores) of students taking Pancasila education courses. The data analysis used is the independent sample $t$ test, which is a statistical test to find out the differences between two samples that are not interconnected. The result of the development is known that virtual learning through the MOOC platform can increasing students' score. That are known from the average of virtual class score than traditional classes, but the level of equality is lower values than virtual classes. This average that not all students in one membership can receive virtual classes equally. The traditional and virtual classes of the Pancasila education has a significant difference.
\end{abstract}

Keywords_-Virtual Learning, MOOC, Pancasila Education, Increasing Score.

\section{Introduction}

The 21 st century education is about developing some of the intelligence and demands of an education system that is holistic and supportive for students to reach their full potential. The environment learning in the 21 st century requires different places, ideas, and people who support technology and support in virtual space rather than physical space [1]. Thus learning in the 21 st century requires learning that is not only present in classes. Learning must also be available in the realm of virtual technology [2]. Traditional teaching and learning skills need to be changed in order to get the maximum benefit from virtual learning [3]. The presence of virtual learning can open up space and greater time learning. Virtual learning has been growing rapidly and have flexible conditions offered to the learners [4], [5]. This flexibility can not only in access to knowledge but also in how to structure learning, facilities and planning that best suits students' needs to achieve knowledge [6]. 
Virtual learning is defined as the delivery of learning through electronic mediation that bridges the gap caused when education and students are separated both in time and place [7]. Virtual learning is the antithesis of traditional learning as where instruction is centered on teachers, linear and limited by class availability, while virtual learning is student-centered, asynchronous, and available anytime and anywhere. Virtual learning is an adjustment to the obsolescence of traditional learning that can be adapted to a particular place, which is more stable and durable [7].

There are a number of benefits of virtual learning, including the following: 1. Every student can do something completely different at the same time; 2 . The virtual environment offers an instructor or facilitator with a lot of control; 3. The facilitator or instructor can oversee how each group and each individual learns; 4. Easy and flexible for students and instructors; 5. Reducing education costs; 6. Beyond geographical barriers and allow participants from all over the world to communicate with each other; 7. Be up to date by getting more useful other sources of information [3]. According to Aitken, traditional classes with face-to-face meetings can increase productivity and performance, but are unable to support the budget, while virtual learning can reach all three, namely increasing productivity, performance, and increasing operational costs [8].

In virtual learning, the teacher's role changes to become a facilitator. Facilitate learning, provide advice and support and assist the group in the learning process. Therefore communication changes from a one-way relationship to a versatile relationship, where students communicate with each other without communicating space and time and are also supported by facilitators [9]. Virtual learning, on the other hand also encourages collaborative learning. Collaborative learning encourages individuals to practice, verify, strengthen and improve their learning models through discussion and information sharing during the problem solving process. The need for people to think and work together on issues of critical concern has increased, shifting the emphasis from efforts to group individual work, to broad collaboration [10].

Therefore, higher education must provide more virtual education, mass-based and interdisciplinary learning[7]. Likewise, Pancasila Education courses must be able to see the future by being present in a virtual space, not just limited to traditional spaces in classrooms. In Indonesia, Pancasila education is only found in classes that have limitations. Not everyone can access pancasila education, which only exists in the class.

\section{MOOC Platform}

Massive Open Online Courses (MOOC) provide a means for unprecedented access to education, across racial, class, age, gender, and geographic boundaries [11], [12]. MOOC are one of the developments in virtual learning as a result of the third wave revolution. MOOC are an online platform have attracted massive audience [13], [14], with content, design, access points, application methods, and definitions of success being open [15], [16], designed for anyone to participate without background knowledge or skills, fee and admission process [17]. It offer a completely virtual 
learning environment, with lectures, discussions and assignments all distributed via the internet, thus presenting considerable advantages for students in terms of flexibility to learn what they want [18] and access to quality education, especially for those who live in remote or disadvantaged areas [19], but it needs to be a concern of students who follow MOOC have dissatisfaction especially with planning, design, and assessment [20].

The characteristics of MOOCs are as follows: learning is regulated by participants; there is a knowledge distribution of processes, knowledge analysis and connections; and participants produce, share, interpret and combine knowledge [15]. MOOCs can provide a new form of learning through technology and eliminate significant financial barriers to education, reduce the gap in global education and be able to achieve and maintain education the less Ichou [11].

In developing MOOC there are various models that were born including the basic model, namely cMOOC, xMOOC, hMOOC, and ahMOOC [21]. In developing this learning innovation, the platform that will be produced is the $\mathrm{xMOOC}$ model, the second wave model. The selection of this model was based on the consideration that the development of this model was an initial development in the Pancasila education course and there were also limited funds and means of development.

The structure of the xMOOC model is as follows: 1 . Spatial development to manage resources and activities, 2. design, scope development and management of resources and activities, 3. Pedagogical methodologies development, sustainability systems development [21]. The basic theory of the xMOOC model above is the basis for the development of this innovation. Based on these theories the steps of developing learning innovations are as follows:

1. Study room development

2. Study room design development

3. Learning methodology development

4. Sustainability development.

\section{Pancasila Education}

Pancasila Education is a course in university program. This provision is based on Article 35 paragraph 5 of Law Number 12 of 2012 concerning Higher Education which states that the curriculum of higher education must include subjects of religious education, Pancasila education, citizenship education, and Indonesian language. According to Margono, Pancasila education is basically a citizenship education family that specializes in instilling the Pancasila ideology into the personality of students as good Indonesian citizens [22]. In other words, Pancasila Education is ideological education in Indonesia [23]. Meanwhile, based on the understanding of the Belmawa Dikti, Pancasila education course is a lesson that provides guidelines for every human being to learn, analyze, and solve the problems of national developmentand state in the perspective of the basic values of Pancasila as the ideology and basis of the Republic of Indonesia [24], [25]. 
From this understanding, it can be formulated that Pancasila education is substantially an ideology education course, a transformation of the ideology knowledge of the Indonesian state, with the expectation that students are related to resolving national problems in the perspective of Pancasila values [26], [27]. In the end Pancasila education can make good citizens who understand their rights and interests as citizens also have a balance of love and nationalism towards the Indonesian state.

There are four base of Pancasila Education, namely historical base, cultural base, juridical base, and philosophical base. Historical base is the historical facts that are used as the basis for the development of Pancasila Education, both concerning the formulation of objectives, material development, design of learning models, and their evaluation. These historical facts range from prehistoric life, old Indonesian history, national glory, the struggle of the Indonesian people against the colonial system, the proclamation of independence, to the struggle to defend and fill Indonesian independence. The cultural base is the development of Pancasila education based on values that are glorified, and therefore agreed upon in national life. There is no society, nation, or country that can survive without the commitment, agreement, and shared ideals of what values underlie that society, nation, and state. Pancasila Education wants to maintain and develop the agreed values of Pancasila. Juridical base concerns the laws and regulations that underlie the implementation of Pancasila education. Hierarchically, the legal basis can be traced from the 1945 Constitution, Parliament Decrees, Laws, Government Regulations, Ministerial Decrees, Director General Decrees, and others. The philosophical base is the use of the results of the philosophical thinking of Pancasila to develop Pancasila education [22].

The purpose of Pancasila Education in Higher Education are to: a. Strengthening of Pancasila as the basis of state philosophy and the nation's ideology through the revitalization of the basic values of Pancasila as the basic norm of community, nation and state life; b.Provide to understanding and appreciation of the soul and basic values of Pancasila to students as citizens of the Republic of Indonesia, and guide them to be able to apply Pancasila values in their life of society, nation and state; c. preparing students to be able to analyze and find solutions to various problems in the community, nation and state through a discussion system that uses the values of the Pancasila and the 1945 Constitution of the Republic of Indonesia; d. forming the mental attitude of students who are able to appreciate the values of divinity, humanity, love for the homeland and national unity, as well as strengthen civil society that is competent, just, and dignified based on Pancasila, to be able to support the internal and external relations of the Indonesian people [24].

Meanwhile, according to Margono the purpose of Pancasila Education in higher education is that students (a) can understand and be able to carry out the spirit of Pancasila and the 1945 Constitution of the Republic of Indonesia in their lives as citizens of Indonesia, (b) mastering knowledge about a variety of basic problems of community life, nationhood, and having a state that is to be overcome by applying ideas based on the Pancasila and the 1945 Constitution of the Republic of Indonesia, (c) fostering attitudes and behaviors that are in accordance with the values and norms of the Pancasila, so that they are able to respond to changes that occur in the context of the integration of science and technology and development, (d) help students in the process of 
learning, thinking processes, problems solving, and making decisions by applying heuristic strategies to the values of Pancasila [22].

Learning Achievements to be achieved from Pancasila Education learning are as follows: a) having analytical skills, thinking rationally, being critical in dealing with social problems, national and state life; b)having the ability and intellectual responsibility in recognizing problems and providing solutions based on Pancasila values; c) able to explain the basic truths that Pancasila is an ideology that is suitable for a pluralistic Indonesian nation (Unity in Diversity); d) able to implement and preserve the values of Pancasila in the reality of life; e) possess the character of Pancasila scientists and professionals who are committed to the survival and glory of the Unitary Republic of Indonesia [24].

According to Margono, the implementation of Pancasila education learning in higher education must be in accordance with the strategies for developing the Pancasila education learning model in higher education, namely lectures must be centered on students with a constructivism approach; not emphasizing the teaching paradigm, but learning; with the active participation of students in problem solving; contains the transfer of values, not the transfer of knowledge [22]. This statement emphasizes that the Pancasila education learning approach puts forward the value transfer paradigm.

In Indonesia, Pancasila education is only found in classes that have limitations. Not everyone can access Pancasila education, which only exists in the class. Yet according to Margono, Pancasila education is basically ideological education in Indonesia[22]. Therefore Pancasila education must be accessible to every Indonesian citizen as part of ideological education. Therefore, there needs to be an online pancasila education course. Development of courses aimed at developing an Open Online Massive Course (MOOC) specifically for Pancasila education. Based on previous research, the use of MOOC can increase student participation in MOOC [28], and improve memory recall [29], but there is no research that explains about MOOC can increase student score.

\section{Method}

This research was designed as a research and development education (R\&D). R\&D is research designed to discover new products and procedures in the field of education that are systematically sponsored, evaluated, and improved to meet the requirements, quality, and standards. In this research, the platform used is the xMOOC model, which is the second wave model. The selection of this model is based on the consideration that the development of this model is an initial development in the Pancasila education course and there are also limited funds and means of development.

The research step was begun by developing the Pancasila Education MOOC, then the students were tested, and the results of the tests were then analyzed learning outcomes. The test was conducted on students of Malang State University who took Pancasila education courses. Classes that are used as research samples are the Office Administration class and the Civil Engineering class. Office Administration Class has 39 students with defined as a traditional class that the class is managed with a traditional system by putting face to face in the classroom. The civil engineering class has 
31 students and designated as a virtual class managed online with the Pancasila education MOOC media developed previously. The test is conducted for one semester, which is odd semester 2018/2019. From the results of trials on students conducted an evaluation of student learning outcomes. The evaluation technique used is the comparison of learning outcomes. Student learning outcomes that are traditionally managed are compared with learning outcomes that are managed virtually. The comparison of learning outcomes will provide information about the success of using MOOC in the Pancasila Education course.

The research instrument used in this study was the learning outcomes (scores) of students taking Pancasila education courses. The data analysis used is the t-test independent sample, which is a statistical test to find out the differences between two samples that are not interconnected.

\section{$5 \quad$ Result and Discussion}

The results of this research are Pancasila Education MOOC platform with a website address: kursus.lab.pancasila.um.ac.id. The MOOC platform is tested on students by using a comparison method that compares the results of evaluations of traditional classes with virtual classes MOOC platform. The test is carried out for one semester which is approximately 16 meetings. The class that was the test subject was the Office Administration Class of 2018 using the traditional approach and the Civil Engineering Class of 2018 with a virtual class approach. Both of these classes have the same ability, but get different learning methods, so that the results being compared do not represent the basic abilities of students in the class, rather than the results of the learning methods applied. Comparison of learning outcomes will represent the success of the methods applied to each class.

Other than that, both of these classes are outside the Pancasila and Citizenship Education study program, meaning that students who are subjected to the trial do not have a Pancasila and citizenship scientific basis, so the results obtained can represent the methods and approaches used. The results of the evaluation of learning of students who are subject to research are as follows:

\subsection{Evaluation results of traditional classes}

The results of traditional classes evaluation can be seen in the following table: 
Table 1. Evaluation of Traditional Classes

\begin{tabular}{|c|c|c|c|c|c|c|c|c|}
\hline No & $\begin{array}{c}\text { Class } \\
\text { Interval }\end{array}$ & Frequency & $\begin{array}{c}\text { Middle } \\
\text { Value }\end{array}$ & $\begin{array}{c}\text { Relative } \\
\text { Frequen- } \\
\text { cy }\end{array}$ & $\begin{array}{c}\text { Cumulative } \\
\text { Frequency } \\
<\end{array}$ & $\begin{array}{c}\% \\
\text { Cumula } \\
\text { tive Frequency< }\end{array}$ & $\begin{array}{c}\text { Cumulative } \\
\text { Frequ- } \\
\text { ency }\end{array}$ & $\begin{array}{c}\% \\
\text { Cumulative } \\
\text { Frequency }>\end{array}$ \\
\hline 1 & $44-49$ & 2 & 46,5 & 5,13 & 2 & 5,13 & 39 & 100 \\
\hline 2 & $50-55$ & 1 & 52,5 & 2,56 & 3 & 7,69 & 37 & 94,87 \\
\hline 3 & $56-61$ & 6 & 58,5 & 15,38 & 9 & 23,08 & 36 & 92,31 \\
\hline 4 & $62-67$ & 12 & 64,5 & 30,77 & 21 & 53,85 & 30 & 76,92 \\
\hline 5 & $68-73$ & 12 & 70,5 & 30,77 & 33 & 84,62 & 18 & 46,15 \\
\hline 6 & $74-79$ & 6 & 76,5 & 15,38 & 39 & 100 & 6 & 15,38 \\
\hline \multicolumn{2}{|c|}{ Total } & 39 & & 100 & & & & \\
\hline
\end{tabular}

Table 2. Descriptive Data Evaluation of Traditional Classes

\begin{tabular}{|c|c|c|c|c|c|c|}
\hline N & Range & Minimum & Maximum & Mean & Std. Deviation & Variance \\
\hline 39 & 34.00 & 44.00 & 78.00 & 65.49 & 7.47 & 55.73 \\
\hline
\end{tabular}

\subsection{Evaluation results of virtual classes}

The results of virtual classes evaluation can be seen in the following table:

Table 3. Evaluation of Virtual Classes

\begin{tabular}{|c|c|c|c|c|c|c|c|c|}
\hline No & $\begin{array}{c}\text { Class } \\
\text { Interval }\end{array}$ & $\begin{array}{c}\text { Frequen- } \\
\text { cy }\end{array}$ & $\begin{array}{c}\text { Middle } \\
\text { Value }\end{array}$ & $\begin{array}{c}\text { Relative } \\
\text { Frequen- } \\
\text { cy }\end{array}$ & $\begin{array}{c}\text { Cumulative } \\
\text { Frequency< }\end{array}$ & $\begin{array}{c}\text { Cumulativ } \\
\text { e Frequency }\end{array}$ & $\begin{array}{c}\text { e } \\
\text { Frequency } \\
>\end{array}$ & $\begin{array}{c}\text { Cumulative } \\
\text { Frequency> }\end{array}$ \\
\hline 1 & $60-65$ & 4 & 62,5 & 12,9 & 4 & 12,9 & 31 & 100 \\
\hline 2 & $66-71$ & 8 & 68,5 & 25,83 & 12 & 38,71 & 27 & 87,1 \\
\hline 3 & $72-77$ & 6 & 74,5 & 19,35 & 18 & 58,06 & 19 & 61,29 \\
\hline 4 & $78-83$ & 8 & 80,5 & 25,81 & 26 & 83,87 & 13 & 41,94 \\
\hline 5 & $84-89$ & 5 & 86,5 & 16,13 & 31 & 100 & 5 & 16,13 \\
\hline \multicolumn{2}{|c|}{ Total } & 31 & & 100 & & & & \\
\hline
\end{tabular}

Table 4. Descriptive Data Evaluation of Virtual Classes

\begin{tabular}{|c|c|c|c|c|c|c|}
\hline $\mathbf{N}$ & Range & Minimum & Maximum & Mean & Std. Deviation & Variance \\
\hline 31 & 34.00 & 55.00 & 89.00 & 74.55 & 10.06 & 101.26 \\
\hline
\end{tabular}

From the descriptive data presented above shows that there are differences between traditional and virtual classes. Judging from the average value obtained, it is known that the class that is managed in the traditionally is 65.49 , while the class that is managed in a virtually is 74.55. The average difference experienced an increase even though the difference was not too striking at 9.06. This is understandable because the development of the Pancasila Education MOOC that is being applied is still in the development stage so that the expected results are not so optimal. Development of Pancasila Education MOOC continues to be developed to obtain satisfactory results. Judging from the deviation of data between traditional classes and virtual classes also 
show different data. The standard deviation of the traditional class is 7.47 , while the virtual class is 10,06 . This data shows that the use of virtual approach in Pancasila Education is still unable to be absorbed and followed by most students, because the spread of data from the average is still quite large.

If drawn in the form of a histogram can be seen in the chart below:

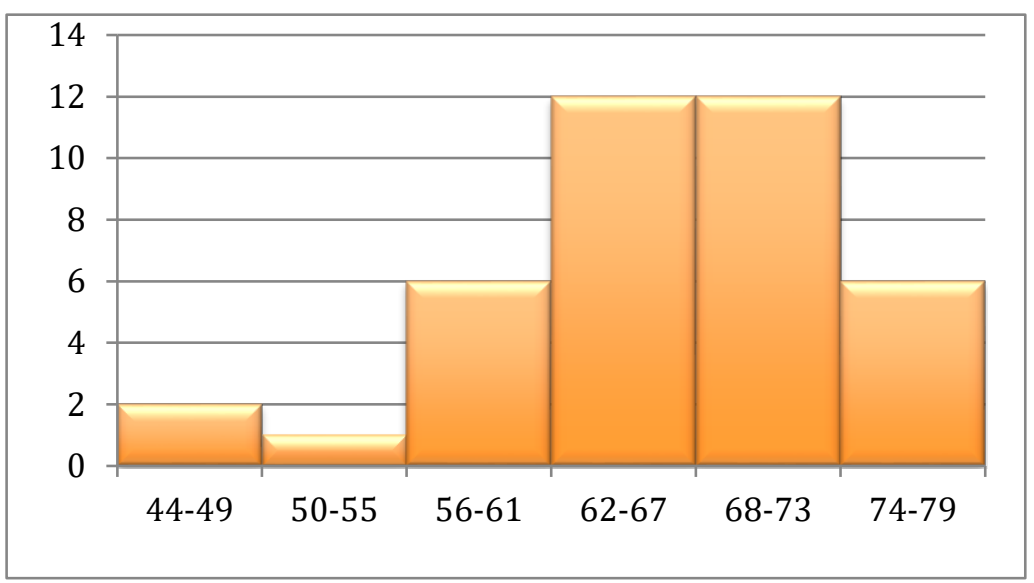

Fig. 1. Evaluation Value of Traditional Classes

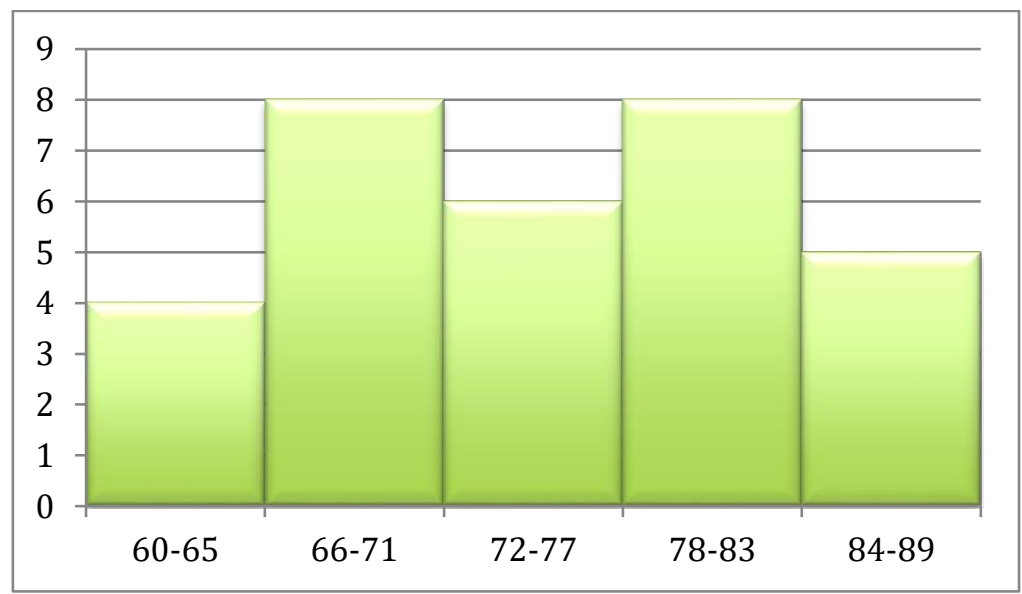

Fig. 2. Evaluation Value of Virtual Classes

Then a different test is conducted on the results of evaluations of traditional classes and virtual classes. Different tests are performed using an independent sample t-test, because the test is to find out whether there are differences in the average of two unpaired samples between traditional classes and virtual classes. Sig. (2-tailed) $<0.05$ then there is a significant difference, and the Sig. (2-tailed)> 0.05 then there is no significant difference. 
Table 5. Results of t-Test Idependent Sample

\begin{tabular}{|c|c|c|l|}
\hline No & Sig. & Sig. (2-tailed) & Decision \\
\hline 1 & 0,05 & 0,00 & There are Significant Differences \\
\hline
\end{tabular}

From the results of t-test idependent sample for classes that are traditional classes and virtual classes (see table 5), the Sig. (2-tailed) is 0.00 , the Sig. (2-tailed) $<0.05$ so that it can be concluded that there are significant differences between traditional classes and virtual classes. Thus, the traditional and virtual classes of the Pancasila Education has a significant difference. From the test results it is known that the results of the virtual classes have a higher score than the score of the traditional class, so there are significant differences.

From the results of a comparison test between traditional classes and virtual classes shows that the use of MOOC in learning Pancasila education courses can increase student score on average. This shows that open access to students to obtain information from various sources can increase students' knowledge in mastering the material provided in the course. However, the nature of the course that is open, the instructor and the participants are not in one forum, so the supervision of the tests conducted is not as strict as traditional classes. This also indicates that the increase in student score results is due to the openness of participants to access information when the test is taking place. In subsequent studies, it is necessary to pay attention to external variables that affect test takers who will conduct the test in MOOC.

\section{Conclusion}

The virtual learning capability with massive open online courses (MOOC) in the face of the 21st century learning era in the Pancasila Education course shows an increase in learning outcomes compared to traditional classes. The average value of virtual classes is higher than traditional classes, which indicates that virtual learning can improve student learning outcomes. However, the standard deviation of learning outcomes is still greater than the traditional class. This indicates that in the virtual classroom there is a gap between students who are learning virtually. Students who are able to take virtual classes have high grades, but who cannot follow the results well below, so that the learning outcomes are still inferior to traditional classes. From the results of the different tests it was concluded that there was a significant difference between the average value of traditional classe and virtual classes.

In further research, it is also important to consider the openness of information access of course participants when taking the exam. When course participants take the exam, they can access information related to the exam without the supervision of the instructor, so as to improve the score of learning outcomes. In this study, researchers have not paid attention to these factors, so in subsequent studies there must be control of the open access to information in question. 


\section{$7 \quad$ References}

[1] W.-C. Liu and E.-L. Low, "Editorial: teacher education for the 21st century," Educ. Res. Policy Pract., vol. 14, no. 3, pp. 189-191, Oct. 2015, doi: 10.1007/s10671-015-9188-x.

[2] Y. Zhang, J. Chen, D. Miao, and C. Zhang, "Design and Analysis of an Interactive MOOC Teaching System Based on Virtual Reality," Int. J. Emerg. Technol. Learn. IJET, vol. 13, no. 07, pp. 111-123, Jun. 2018. https://doi.org/10.3991/ijet.v13i07.8790

[3] Elspeth McFadzean, "Supporting virtual learning groups. Part 2: an integrated approach," Team Perform. Manag. Int. J., vol. 7, no. 5/6, pp. 77-93, Sep. 2001, doi: $10.1108 / 13527590110403630$.

[4] H. Ng and S. S. Baharom, "An Analysis on Adult Learners' Satisfaction in Online Education Programmes," Int. J. Interact. Mob. Technol. IJIM, vol. 12, no. 7, pp. 70-85, Nov. 2018. https://doi.org/10.3991/ijim.v12i7.9665

[5] F. Fotouhi-Ghazvini, R. Earnshaw, A. Moeini, D. Robison, and P. Excell, "From ELearning to M-Learning - the use of Mixed Reality Games as a new Educational Paradigm," Int. J. Interact. Mob. Technol. IJIM, vol. 5, no. 2, pp. 17-25, Mar. 2011. https://doi.org/10.3991/ijim.v5i2.1463

[6] M. D. F. Goulão, "Virtual Learning Styles: Does Gender Matter?" Procedia - Soc. Behav. Sci., vol. 106, no. Supplement C, pp. 3345-3354, Dec. 2013, https://doi.org/10.1016/j.sbspro.2013.12.387

[7] Peter W. Stonebraker and James E. Hazeltine, "Virtual learning effectiveness: An examination of the process," Learn. Organ., vol. 11, no. 3, pp. 209-225, Jun. 2004, doi: $10.1108 / 09696470410532987$.

[8] Rachel Aitken, "Building for the future with virtual learning," Strateg. HR Rev., vol. 9, no. 1, pp. 29-34, Nov. 2009, doi: 10.1108/14754391011007106.

[9] Elspeth McFadzean and Jane McKenzie, "Facilitating virtual learning groups: A practical approach," J. Manag. Dev., vol. 20, no. 6, pp. 470-494, Aug. 2001, https://doi.org/10.1108/02621710110399774

[10] M. Laal, M. Laal, and Z. K. Kermanshahi, "21st Century Learning; Learning in Collaboration,” Procedia - Soc. Behav. Sci., vol. 47, no. Supplement C, pp. 1696-1701, Jan. 2012, https://doi.org/10.1016/j.sbspro.2012.06.885

[11] R. Pollack Ichou, "Can MOOCs reduce global inequality in education?" Australas. Mark. J. AMJ, vol. 26, no. 2, pp. 116-120, May 2018, https://doi.org/10.1016/j.ausmj.2018.05.007

[12] H. W. You, "Students' Perception about Learning using MOOC," Int. J. Emerg. Technol. Learn. IJET, vol. 14, no. 18, pp. 203-208, Sep. 2019. https://doi.org/10.3991 lijet.v14i18.10802

[13] S. Korkut, R. Dornberger, P. Diwanji, B. P. Simon, and M. Maerki, "Success Factors of Online Learning Videos,” Int. J. Interact. Mob. Technol. IJIM, vol. 9, no. 4, pp. 17-22, Sep. 2015. https://doi.org/10.3991/ijim.v9i4.4460

[14] J. Li, "Construction of Modern Educational Technology MOOC Platform Based on Courseware Resource Storage System," Int. J. Emerg. Technol. Learn. IJET, vol. 12, no. 09, pp. 105-116, Sep. 2017. https://doi.org/10.3991/ijet.v12i09.7491

[15] Emigawaty, "Perancangan Arsitektur dan Purwarupa Model Pembelajaran Massive Open Online Course (MOOCs) di Perguruan Tinggi Menggunakan Layanan Mobile,” Jurnal Ilmiah DASI, vol. Vol. 18 No. 1 Hlm. 25-30, pp. 25-30, Mar. 2017.

[16] D. Gamage, I. Perera, and S. Fernando, "Exploring MOOC User Behaviors Beyond Platforms,” Int. J. Emerg. Technol. Learn. IJET, vol. 15, no. 08, pp. 161-179, Apr. 2020. https://doi.org/10.3991/ijet.v15i08.12493 
[17] M. Ghosh, "MOOC M4D: An Overview and Learner's Viewpoint on Autumn 2013 Course," Int. J. Interact. Mob. Technol. IJIM, vol. 8, no. 1, pp. 46-50, Jan. 2014. https://doi.org/10.3991/ijim.v8i1.3486

[18] M. Bulger, J. Bright, and C. Cobo, "The real component of virtual learning: motivations for face-to-face MOOC meetings in developing and industrialised countries," Inf. Commun. Soc., vol. 18, no. 10, pp. 1200-1216, Oct. 2015, https://doi.org/10.1080/1369118x. 2015.1061571

[19] T. Daradoumis, R. Bassi, F. Xhafa, and S. Caballé, "A Review on Massive E-Learning (MOOC) Design, Delivery and Assessment," in 2013 Eighth International Conference on P2P, Parallel, Grid, Cloud and Internet Computing, Oct. 2013, pp. 208-213, https://doi.org/10.1109/3pgcic.2013.37

[20] E. Gutiérrez-Santiuste, V.-M. Gámiz-Sánchez, and J. Gutiérrez-Pérez, "MOOC \& Blearning: Students' Barriers and Satisfaction in Formal and Non-formal Learning Environments.," J. Interact. Online Learn., vol. 13, no. 3, 2015.

[21] F. J. García-Peñalvo, Á. Fidalgo-Blanco, and M. L. Sein-Echaluce, “An adaptive hybrid MOOC model: Disrupting the MOOC concept in higher education," Telemat. Inform., vol. 35, no. 4, pp. 1018-1030, Jul. 2018, https://doi.org/10.1016/j.tele.2017.09.012

[22] Margono, Pendidikan Pancasila: Topik Aktual Kenegaraan dan Kebangsaan. Malang: Unit Pelaksana Matakuliah Umum FIP UM, 2001.

[23] S. Amir, "Pancasila as integration philosophy of education and national character," Int. J. Sci. Technol. Res., vol. 2, no. 1, pp. 54-57, 2013.

[24] B. Dikti, Materi Ajar Mata Kuliah Pendidikan Pancasila. Jakarta: Kementerian Pendidikan dan Kebudayaan, 2013.

[25] S. Nishimura, “The Development of Pancasila Moral Education in Indonesia," 東南アジ ア研究, vol. 33, no. 3, pp. 303-316, 1995, doi: 10.20495/tak.33.3_303.

[26] T. Taniredja, M. Afandi, and E. M. Faridli, "The Appropriate Pancasila Education Contents to Implant Lofty Values for Indonesian Students," EDUCARE, vol. 5, no. 1, 2012.

[27] I. Gunawan, "Perspectives of Pancasila: Leadership Education's Values and Ethics," 2nd ICET Theme"Improving Qual. Educ. Train. Strength. Networking," p. 417, 2016.

[28] S. Jiang, A. Williams, K. Schenke, M. Warschauer, and D. O'dowd, "Predicting MOOC performance with week 1 behavior," in Educational data mining 2014, 2014.

[29] E. Busri, "The Development of MOOC Media to Increase Recall Memory Skill on Physics at Vocational High School," in Journal of Physics: Conference Series, 2019, vol. 1351, no. 1, p. 012017. https://doi.org/10.1088/1742-6596/1351/1/012017

\section{Authors}

Didik Sukriono is a lecturer in the Department of Law and Citizenship, Faculty of Social Sciences, Universitas Negeri Malang (Malang State University), J1. Semarang No. 5 Malang 65145, Indonesia. Email: didik.sukriono.fis@um.ac.id

Sudirman is a lecturer in the Department of Law and Citizenship, Faculty of Social Sciences, Universitas Negeri Malang (Malang State University), J1. Semarang No. 5 Malang 65145, Indonesia. Email: sudirman.fis@um.ac.id

Article submitted 2020-05-09. Resubmitted 2020-05-28. Final acceptance 2020-05-29. Final version published as submitted by the authors. 